Historia i Polityka

Półrocznik poświęcony myśli politycznej i stosunkom międzynarodowym

$\mathrm{Nr} 9(16) / 201381-96$

DOI: http://dx.doi.org/10.12775/HiP.2013.006

Mariusz Strużyński (Uniwersytet im. Adama Mickiewicza - Poznań)

\title{
Hamas wobec sporu palestyńsko-izraelskiego. Między procesem pokojowym a eskalacją konfliktu
}

\author{
Hamas to the Palestinian-Israeli dispute. \\ Between the peace process and the escalation of the conflict
}

Issues around which the focus is at stake, for the ongoing Holy Land in the Israeli-Palestinian conflict and its impact on the Islamic Resistance Movement. The dispute, which still has not found a solution took on the character of the war of civilization of Islam and the West. Significantly expanded its boundaries and is not just a conflict over land, but the conflict unfolding on several levels - military, ethnic and religious controversy, which engage in other countries recognizing the danger of its further escalation. This article aims to analyze the role of Hamas in the disputed territories, its origins, the links ideological organizational structure. The starting point for the delineation of the relationship is to present contemporary political events and the analysis of stereotypes and misconceptions, chich became the basis of mutual aversion two years warring sides in the conflict.

Słowa klucze: Hamas, Mariusz Strużyński, konflikt palestyńsko-izraelski, terroryzm, Strefa Gazy, Hamas to the Palestinian-Israeli dispute

\section{Wstęp}

Korzenie Hamasu sięgają początku XX wieku, gdy w roku 1928 w Egipcie uformowała się organizacja pod nazwą Bracia Muzułmanie. Początek działalności Bractwa w Palestynie sięgał 1935 roku. Wtedy to Hasann Al-Banna utworzył Generalny Komitet Centralny do spraw Pomocy Palestynie. Od samego początku filia była mocno zaangażowana w sprawę palestyńską. Protestowano przeciwko brytyjskim wpływom oraz planom utworzenia państwa Izrael. W roku 1936 działania stowarzyszenia nasiliły się, członkowie Bractwa aktywnie wspierali ataki na brytyjskie oraz żydowskie interesy w ramach „rewolty 1936”. Bractwo w szybkim tempie rozszerzyło swoje wpływy na terenie całej Palestyny. Niespełna po dwóch 
latach od oficjalnego otwarcia pierwszej filii udało utworzyć się kolejnych 25, w których liczba członków wahała się od 12 do 20 tysięcy ${ }^{1}$.

Do dzisiaj Hamas szczyci się swoimi niechlubnymi korzeniami związanymi $\mathrm{z}$ ruchami przeciwko Izraelowi. Albowiem w 1948 roku, gdy Izrael zdobył niepodległość, rozpoczęła się fala zamachów oraz dążenie do zwalczenia nowego państwa. Ich głównymi propagatorami byli ochotnicy Braci Muzułmanów działający zarówno w głębokiej konspiracji jak i również oficjalnie, w batalionach bractwa. Następne lata nie przyniosły bractwu zbyt wiele sukcesów. Po roku 1948 filie w Gazie znalazły się pod jurysdykcją Egiptu, a oddziały na Zachodnim Brzegu poddane były wpływom jordańskim. Lata 1948-1967 były okresem stagnacji dla Braci Muzułmanów, pod naciskiem państw zwierzchniczych organizacja zawiesiła niemal całkowicie swoje dążenia antyizraelskie. Wszystko uległo zmianie po Izraelskim zwycięstwie w wojnie sześciodniowej w 1967 roku, w wyniku której Izrael odzyskał Strefę Gazy oraz Zachodni Brzeg. Wynik wojny sześciodniowej definitywnie oddzielił Strefę Gazy od Egiptu oraz po części Zachodni Brzeg od wpływów jordańskich. Był to sygnał dla ugrupowania do „wyjścia z cienia” oraz dokonania szybkiej reorganizacji, która skupić się miała jedynie na lokalnej palestyńskiej społeczności. O ile w początkach istnienia działalności Braci Muzułmanów na terenie Palestyny dotyczyła walki partyzanckiej, tak od tej pory główną uwagę skupiono na intensyfikowanie działań związanych z działalnością meczetów. Od tamtego czasu meczety stały się swoistymi ośrodkami społeczno--kulturowymi poprzez działalność charytatywną, wspieranie systemu szkolnictwa zarówno na poziomie podstawowym jak i wyższym. Czołowi przedstawiciele Bractwa szybko zdali sobie sprawę, że wplatanie ideologii w każdy przejaw życia społecznego spowoduje szybki przyrost zwolenników organizacji. Meczety szybko przestały być tylko miejscem kultu, ponieważ przejęły rolę szkół, uniwersytetów, przedszkoli, a nawet bibliotek ${ }^{2}$. Przy meczetach funkcjonowały również rozmaite organizacje wspomagające działalność charytatywną na poziome lokalnym. Organizacje te przez dłuższy czas były niczym niezwiązane z działalnością antyizraelską, a tym bardziej ze stosowaniem przemocy. Ich rola skupiała się głównie na budowaniu społecznej tożsamości opartej na fundamentalnych zasadach islamu, to też od końca lat sześćdziesiątych do połowy lat osiemdziesiątych trwał ich bujny rozkwit. Popularną metodą finansowania takiej działalności był zakat, czyli pieniądze pochodzące z jałmużny. Jednak znaczące środki przypadające na ten okres pochodziły właśnie od rządu Izraelskiego ${ }^{3}$.

1 B. Bolechów, Terroryzm w świecie podwubiegunowym: przewartościowania i kontynuacje, Toruń 2002, s. 307; E. Pace, P. Stefani, Wspótczesny fundamentalizm religijny, Karków 2002, s. 76.

2 M. Levitt, Hamas, polityka, dobroczynność i terroryzm w stużbie dżihadu, Kraków 2008, s. 29.

3 Ibidem, s. 30-33. 
Aktywnie wspierani Bracia Muzułmanie mogli w końcu bez przeszkód skupić się na wewnętrznej strukturze organizacji oraz poczynić następny krok związany z przygotowaniami do „otwartej walki”. Stworzyły się dogodne warunki dla utworzenia nowej, posiadającej nieco odmienny charakter organizacji. W roku 1978 za zgodą Izraela zostało prawnie zarejestrowane Islamskie Stowarzyszenie o nazwie Al. Mujamma Al Islami (Centrum Islamskie) przez Szejka Ahmeda Yassina, duchowego lidera ruchu. Hamas od samego początku aktywnie wykorzystywał dotychczasowy dorobek Braci Muzułmanów poprzez szerzenie religijnej propagandy oraz nakłaniania społeczeństwa do ścisłego przestrzegania zasad Koranu. Pod osłoną działalności społecznej aktywnie przygotowywano się do przyjęcia nowego „rewolucyjnego pokolenia”. Wraz ze wzrostem antyizraelskich nastrojów zwiększało się poparcie dla Mujamma Al Islami, który w swych ideologicznych dążeniach stosował coraz bardziej gwałtowne, ocierające się o przemoc metody. Organizacja pod osłoną działalności społecznej stopniowo poczęła przekształcać się w zbrojny odłam Braci Muzułmanów posiadający rzesze zwolenników tzw. „nowej generacji”. Następnym czynnikiem wskazującym na fakt czynnego udziału wobec izraelskiej polityki była zainspirowana przez radykalną frakcję OWP przy współpracy z częścią członków Stowarzyszenia Braci Muzułmanów zmiana nazwy na Islamski Ruch Oporu. W takich warunkach narodziła się nowa organizacja, która swoje bezpośrednie powołanie do życia zawdzięczała istotnemu wydarzeniu jakim było powstanie Intifady ${ }^{4}$. Intifada to zjawisko, do którego doszło na tle społecznym i politycznym, w wyniku którego powstała organizacja będąca zwiastunem nastania nowej epoki w relacjach palestyńsko-izraelskich. Izraelskie służby specjalne w pierwszej chwili z radością przyjęły powstanie tego ugrupowania, widząc w nim osłabienie pozycji OWP i Jasira Arafata wśród mieszkańców terenów okupowanych. Izraelscy eksperci przypuszczali, że pojawienie się Hamasu zacznie jednoczyć Palestyńczyków wokół religijnego zaangażowania i społecznego solidaryzmu. Jednak organizacja ta nie dała się w żaden sposób sterować i bardzo szybko dostosowała się do sytuacji panującej w Palestynie. Przywódcy Hamasu wykorzystywali do swych celów organizacje społeczne, legalne struktury polityczne czy też meczety. Znajdując posłuch wśród coraz bardziej radykalizującego się społeczeństwa stopniowo rosła w siłę, aby stać się czołowym ugrupowaniem fundamentalistycznym ${ }^{5}$.

4 Bezpośrednia przyczyną powstania była śmierć 4 arabów w zderzeniu ich samochodu z izraelskimi ciężarówkami. Podłoże stanowiło również głębokie niezadowolenie ludności palestyńskiej z powodu impasu w konflikcie palestyńsko izraelskim oraz marginalizacji problemu na arenie międzynarodowej, http://www.stosunkimiedzynarodowe.info/haslo,intifada (dostęp: 12.09.2013 r.).

5 Ł. Marciniak, Między fundamentalizmem a terroryzmem islamskim, Włocławek 2011, s. 52. 


\section{Hamas - ideologia, struktura oraz metody działania}

Główne założenia ideologiczne zostały zawarte w „Konwencji Islamskiego Ruchu Oporu” będąca ogólnym manifestem, składającym się z 36 oddzielnych artykułów, które określają cele i sposoby działania organizacji. W dokumencie tym znajdujemy prezentację organizacji, której celem jest „podniesienie sztandaru Allacha nad każdym centymetrem Palestyny” i czytamy o „ruchu oporu”, który „z islamu czerpie swoje idee, pojęcia i poglądy dotyczące wszechświata, życia i człowieka, i we wszystkich swoich działaniach nawiązuje do wartości islamu.

Islamski ruch oporu jest wyróżniającym się ruchem palestyńskim, którego podstawowym założeniem jest wiara w Allaha i życie zgodnie z zasadami Islamu. Jego usilnym staraniem jest rozpowszechnienie wielkości Allaha na każdym centymetrze Palestyny ${ }^{6}$.

Już we wstępie dokumentu został jasno zdefiniowany wróg organizacji. Organizacja nawoływała wszystkich wyznawców islamu do wspólnej walki, wskazując na zagrożenie, jakie sobą zaniosło ustanowienie państwa żydowskiego w Palestynie.

Dokument z aprobatą cytuje Hasana Al-Banna, który stwierdza, że „Izrael będzie istniał, dopóki islam go nie zlikwiduje”. O Izraelu nie pisze jak o państwie terrorystycznym, lecz o państwie, którego istnienie jest nieprawomocne, ponieważ Palestyna jest „świętą ziemią muzułmanów”. Innymi słowy, nie może istnieć państwo Izrael przede wszystkim dlatego, że „niewierni” nie mogą sprawować władzy na tak zwanej islamskiej ziemi: Islamski Ruch Oporu stwierdza, że ziemia Palestyny jest Waqf (religijnie niezbywalna), jest darowizną dla wszystkich pokoleń muzułmanów aż do Dnia Zmartwychwstania (...) Jest jak każda ziemia, którą muzułmanie zdobyli siłą, ponieważ muzułmanie ją wówczas poświęcili jako religijny dar dla wszystkich pokoleń muzułmanów aż do Dnia Zmartwychwstania (...) Waqf będzie istniał tak długo, jak długo istnieje niebo i ziemia. Nic co dotyczy Palestyny, a co nie podporządkowuje się temu prawu islamskiemu, nie ma mocy prawnej

Znaczenie Jerozolimy jednego z najważniejszych miejsc dla muzułmanów zostało podkreślone w programie ideowym Hamasu jako ziemia ku której kierują się muzułmanie wznosząc swe modlitwy i punkt z którego o północy Mahomet wyruszył ku siedmiu niebiosom. Fundamentalistyczne podejście do statusu Jerozolimy oznaczało brak jakiejkolwiek zgody o włączeniu tego miejsca do rozmów pokojowych. Islamskie zwierzchnictwo nad Jerozolimą, a w szczególności Wzgó-

6 Hamas w: http://www.izrael.badacz.org/historia/intifada_hamas.html (dostęp: 25.03.2013 r.).

7 Hamas, 18 sierpnia 1988, 'The Covenant of the Islamic Resistance Movement-Hamas', tłum. $\mathrm{Na}$ ang. przez Middle East Media Research Institute. 
rzem Świątynnym z meczetami Kopuła na Skale i Al-Aksa stanowiły dogmat Islamskiego Ruchu Oporu8

Karta Hamasu demonizuje Izrael w takim stopniu, iż przyczynia się do pełnego utrwalenia stanowiska iż kompromis w sprawie palestyńsko-żydowskiej jest niemożliwy.

Hamas wskazywał Dżihad - świętą wojnę z niewiernymi w obronie własnych wartości i ziemi, jako indywidualny obowiązek każdego muzułmanina. Jego ideolodzy uważali jednak, że konieczne było obudzenie w społeczności „ducha dżihadu" za pomocą odpowiedniego procesu kształcenia. Ten obowiązek spoczywał na nauczycielach, wychowawcach, naukowcach. Była to różnica w ideologii, pomiędzy Hamasem a Bractwem, dla których dżihad był obowiązkiem zbiorowym, a nie nakazem dla pojedynczego członka społeczności. Pomimo ideologicznej rozbieżności Islamski Ruch Oporu nigdy nie zerwał swoich stosunków z Bractwem stając się „grupą frontów Braci Muzułmanów” odpowiedzialną za zbrojne prowadzenie działalności przeciwko Izraelowi. Dzięki takim zabiegom Hamas dał możliwość włączenia się Bractwa do aktywnej działalności przeciwko okupantowi, a zarazem umożliwił zachowanie statusu legalności organizacji?.

Mimo iż Hamas szczyci się korzeniami wywodzonymi ze Stowarzyszenia Braci Muzułmanów, a także głosi pogląd o ideologicznej nierozłączności tychże organizacji, jego filozoficzny punk widzenia na niektóre aspekty znacząco odbiega od wyznaczonego wzorca ${ }^{10}$. Posiadanie zarysu, ścisłego związku oraz rozbieżności obu tych organizacji jest kluczowe dla przedstawienia jednego z głównych elementów funkcjonowania mechanizmów hamasowskiej ideologii, którym jest „system Dawa”.

Znaczenie słowa „Dawa” dosłownie oznacza „powołanie”, „nauczanie”, „zbliżenie się do religii”. W odniesieniu do Hamasu polega na „przyciąganiu” potencjalnych zwolenników. Aktywność „dawa” stanowi system pomocy przewidzianej przez Hamas do Palestyńczyków i ich wyznawców w różnych obszarach tak jak religia, edukacja, zdrowie itd. Celem Hamasu jest poszerzanie i wzmacnianie jej statusu wśród Palestyńczyków, oraz zamiar stworzenia alternatywnej infrastruktury cywilnej, która umożliwi zastąpienie świeckiego rządu Autonomii Palestyńskiej rządem islamskim ${ }^{11}$.

8 A. Krawczyk, Terroryzm ugrupowań fundamentalistycznych na obszarze Izraela w drugiej potowie XX wieku, Katowice 2007, s. 196.

9 M. Levitt, op. cit., s. 43.

10 Encyklopedia terroryzmu, Warszawa 2004, s. 396.

11 Dawa - Hamas' Civilian Infrastructure and its Role in Terror Financing, http://www.shabak.gov.il/English/EnTerrorData/Reviews/Pages/Dawa\%E2\%80\%93Hamas-report.aspx (dostęp: 25.03.2013 r.). 
Hamasowski system Dawa za jeden z głównych celów stawia sobie odbudowę domów zniszczonych w efekcie izraelskich akcji odwetowych, a także budowanie nowych osiedli dla najuboższych pochodzących właśnie z obozów dla uchodźców. Nacisk kładzie się również na budowę centrów medycznych ośrodków rehabilitacyjnych oraz domów opieki społecznej ${ }^{12}$.

Hamas jest ruchem działającym na dwóch płaszczyznach: społecznej i politycznej. Na czele organizacji stanęła „Rada Konsultacyjna” mająca kompetencje zarządzające i decydująca o kierunkach politycznej działalności organizacji. Radzie podporządkowane są komitety odpowiedzialne za działalność na najwyższych polach aktywności. Niezmiennie ważnym elementem struktury organizacyjnej było tzw. zewnętrzne kierownictwo Hamasu rezydujące poza Zachodnim Brzegiem i Strefą Gazy ${ }^{13}$.

W okresie pierwszych kilku lat funkcjonowania organizacji istniały następujące elementy wewnętrznej struktury organizacyjnej wspominany wyżej wydział opieki społecznej i administracyjnej (dawa), wydział bezpieczeństwa (dżihaz Aman) - odpowiedzialny za zbieranie informacji o kolaborantach, oraz za ich eliminację, wydział medialny (Ilam) - do którego kompetencji należała propaganda. W celi zwiększenia efektywności działań grupy w styczniu 1991 roku powołano do życia Brygady Izz ad-Dina ak-Kassama ${ }^{14}$. Włączono do niej dwie działające już grupy Madżd i Al. - Mudżahidum al. Filistinum. Madżd nazywana Grupą do spraw Świętej Wojny i Działalności Misyjnej. Pierwsza była siła uderzeniową wydziału bezpieczeństwa; druga grupa powstała zaś, przed utworzeniem Hamasu, zajmowała się najpierw dostarczaniem broni walczącym Palestyńczykom, a po wybuchu intifady odpowiedzialna była za przeprowadzanie zamachów terrorystycznych ${ }^{15}$.

Od początku swojego istnienia Hamas otrzymywał środki finansowe na swoją działalność ze źródeł prywatnych i publicznych. Wspierały go rządy niektórych państw muzułmańskich. Jednym z najważniejszych sponsorów Hamasu był Iran. Już w połowie lat dziewięćdziesiątych XX wieku wielkość udzielanego tejże organizacji wsparcia wynosiła ok. 30 mln dolarów. Iran nawiązywał także z Hamasem stosunki dyplomatyczne otwierając w Teheranie ambasadę organizacji.

12 A. Krawczyk, Działalność Dawa - społeczno-propagandowego skrzydta Islamskiego Ruchu Oporu (Hamas), http://www.adamkrawczyk.com/2-artykuly_07-01-26.html (dostęp: 23.04.2013 r.).

13 A. Wejkszner, Ewolucja terroryzmu motywowanego ideologia religijna salafickiego ruchu globalnego dżihadu, Poznań 2010, s. 117-118.

14 Sama nazwa kassam - pochodzi od nazwiska szejka Izz ad-Dina al-Kassama, który zginął w 1935 r. podczas walki z brytyjskimi wojskami mandatowymi w czasach arabskiego powstania.

15 B. Burston, Background/Hamasvs..abbas:The lethal wild card, a profile, „Haaretz” 29.06.2006, www.haaretz.com/hasen/pages/SheArt.jhtml?item No=529909\&displayTypeCd=1 \&sideCd $=1 \&$ contrass ID=2, (dostęp: 12.04.2013 r.). 
Reżim irański zaoferował Hamasowi ponadto pomoc wojskową w postaci szkoleń paramilitarnych oraz logistyczną. Mimo znaczącego wsparcia politycznego i finansowego Hamasowi udało się utrzymać organizacyjną niezależność. Jednym z pozostałych państw wspierających powyższą grupę była Arabia Saudyjska, która umożliwiła funkcjonowanie w tym kraju szeregu prywatnych organizacji zbierające fundusze na rzecz Islamskiego Ruchu Oporu ${ }^{16}$.

Szczególny wpływ na organizację miały komórki znajdujące się na terenie Jordanii, Syrii oraz Stanów Zjednoczonych. Stamtąd też organizacja pozyskiwała największą część funduszy na swoją działalność. Środki były pozyskiwane dzięki diasporze palestyńskiej działającej w Stanach Zjednoczonych i w krajach Europy Zachodniej (Francji, Niemczech, Wielkiej Brytanii, Holandii i Belgii) ${ }^{17}$.

Mimo, iż Hamas miał swoje przedstawicielstwa w kilku krajach Bliskiego Wschodu, to unikał jakiegokolwiek zaangażowania się w wewnętrzne sprawy tych państw. Khaled Hroub pisał o działalności organizacji w innych państwach, iż „Hamas usiłuje zająć złożoną pozycję pomiędzy oficjalnym i społecznym poziomem, uprawiając $\mathrm{w}$ teorii dwie różne rodzaje polityk. Pierwsza przeznaczona była dla społeczeństwa, dążąc do jego zmobilizowania, domagając się od niego materialnego zaopatrzenia, oraz partycypowania w dżihadzie. Druga przeznaczona dla miejscowego reżimu charakteryzowała się polityką ustępstw i umiarkowaniem, kładła nacisk na nieingerencję w sprawy wewnętrzne. Faktycznie, te dwie polityki były nie do pogodzenia, dlatego, że działalność Hamasu biorącego w obronę zwykłą arabską ludność stanowiło wielokrotnie konflikt z politycznym reżimem. Dlatego w rzeczywistości Hamas nie działał na publicznej płaszczyźnie polityki w krajach arabskich"18.

\section{Hamas - między procesem pokojowym a eskalacją konfliktu}

Hamas chętnie przyznaje, że „Palestyna” jest państwem powstałym w wyniku islamskiego imperializmu, podbitym siłą. Odmawia prawa istnienia Izraelowi, ponieważ nigdy nie wolno zrzec się kraju raz zdobytego przez islam. W oczach Hamasu problem nie polega na tym, że Żydzi nie mają żadnego prawa do ojczyzny, ale na tym, że Żydzi panujący nawet na centymetrze rzekomo muzułmańskiej zie-

16 D. van Natta, Jr. With, T. L. O'Brien, Flow of Saudis 'Cash to Hamas Is Scrutinized, [w:] www.nytimes.com/2003/09/17.world/flow-of-saudis-cash-tohamas-isscrutinized.html, (dostęp: 21.11.2013 r.).

${ }_{17}$ Intelligence and Terrorism Information Center at the Center for Special Studies, http://www. intelligence.org.il/ (dostęp: 23.04.2006 r.).

18 K. Hroub, Hamas: Political Thought and Practice, Washington, D.C. 2000, s. 173. 
mi są bluźnierczym intruzem. Nawet gdyby Izrael poszedł na wszelkie ustępstwa wobec muzułmanów, byłoby to niewystarczające. Niewierni muszą albo egzystować w stanie biernego poddaństwa, albo zostać wyrzuceni. Ten absolutystyczny pogląd na świat powoduje odmowę szukania kompromisu i pokojowego rozwiązania konfliktu. Karta Hamasu stwierdza, że „inicjatywy tak zwanego pokojowego rozwiązania i międzynarodowe konferencje dla rozwiązania problemu palestyńskiego stoją w sprzeczności z zasadami Islamskiego Ruchu Oporu, ponieważ zapomnienie o jakiejkolwiek części Palestyny oznacza zapomnienie wiary islamskiej” oraz że „nie ma innego rozwiązania problemu palestyńskiego jak poprzez dżihad. Inicjatywy, propozycje i konferencje międzynarodowe są stratą czasu i farsą”19.

Takie podejście zradykalizowały jeszcze bardziej Porozumienia z Oslo pomiędzy przedstawicielami Izraela a OWP na czele z Jasirem Arafatem ${ }^{20}$. Zawarte porozumienie otwierało drogę ku palestyńskiej autonomii. Na mocy porozumień z Oslo podpisano Deklaracje Pokojowych Intencji w Waszyngtonie określająca zasady funkcjonowania Autonomii Palestyńskiej w pięcioletnim okresie przejściowym, zakładając jednocześnie, że po zakończeniu tego okresu wejdzie w życie stały statut sprecyzowany w drodze osobnych negocjacji. 4 maja 1994 roku w Kairze podpisano izraelsko palestyńskie Porozumienie Gaz Jerycha. Był to układ o utworzeniu ograniczonej Autonomii Palestyńskiej w Strefie Gazy, która następnie miano rozszerzyć na Zachodni Brzeg Jordanu 25 września 1995 roku. Ten sukces polityczny pozwolił odnieść zwycięstwo Arafatowi w pierwszych wyborach parlamentarnych w Palestynie równolegle marginalizując działalność Hamasu. Na tym tle doszło do rozłamu w organizacji, na grupę „radykałów”, którzy widzieli jedyną drogę spełnienia postulatów organizacji poprzez dżihad i „umiarkowanych”, chcących stworzyć oficjalne struktury organizacji i brać czynny udział w życiu politycznym Autonomii. Ataki terrorystyczne, zamykanie granic presja społeczna spowodowały, że coraz więcej osób było skłonnych widzieć w Izraelu stronę w rozmowach pokojowych niż śmiertelnego wroga $^{21}$. Normalizacji stosunków nie zahamowało zabójstwo premiera izraelskiego Icchaka Rabina, zwolennika pokojowego rozwiązania problemu palestyńskiego. Ten nieoficjalny rozejm między Hamasem, OWP i Izraelem trwał do momentu zabój-

19 E. Standing, Ku rozsadnemu podejściu do kwestii izraelsko-palestyńskiej, tł. M Koraszewska, http://www.racjonalista.pl/kk.php/t,5760 (dostęp: 01.04.2013 r.).

${ }^{20}$ Głównym przeciwnikiem islamskiego Hamasu jest Fatah. W przeciwieństwie do Hamasu jest to organizacja, która określa się jako laicki ruch narodowy. Przez wiele lat przewodził jej Jaser Arafat. Po jego śmierci w 2004 przewodniczącym została Mahmoud Abbas. Fatah był podstawą Organizacji Wyzwolenia Palestyny - zaś po utworzeniu Autonomii Palestyńskiej - jej władz. M. Piskur, Pomiędzy Fatahem i Hamasem - Palestyńczycy podzieleni, http://www.psz.pl/tekst-25885/ Mariusz-Piskur-Pomiedzy-Fatahem-i-Hamasem-Palestynczycy-podzieleni (dostęp: 01.04.2013 r.).

${ }^{21}$ www.izarel.badacz.org/historia/autonomia.html (dostęp: 04.04.2013 r.). 
stwa najbardziej poszukiwanego przez służby izraelskie konstruktora bomb Hamasu Ajjasza. Odwet za śmierć izraelskiego premiera była dość nieodpowiedzialną akcją ze strony służb izraelskich, w sytuacji kiedy Hamas pozostawał od dłuższego czasu w politycznym impasie, radykalne poglądy wśród Palestyńczyków zaczynały tracić na atrakcyjności a proces pokojowy był przyjmowany z optymizmem. Skutkiem tej akcji było ponowne nakręcenie spirali przemocy, w której ginęli przypadkowi ludzi. Śmierć Ajjasza odbiła się szerokim echem wśród społeczności palestyńskich, która widziała w nim ucieleśnienie męczennika. Jego śmierć zjednoczyła naród palestyński na nowo oraz zradykalizowała dużą cześć ludności cywilnej ${ }^{22}$.

Odpowiedź Islamskiego Ruchu Oporu była szybka, krwawa, a co najważniejsze całkowicie pogrzebała szanse na zrealizowanie porozumień z Oslo ${ }^{23}$.

Najbardziej spornym elementem w rokowaniach palestyńsko izraelskich był problem terroryzmu i niedostatecznej walki z tym zjawiskiem ze strony arabskiej. Włączenie się Stanów Zjednoczonych w proces zaczęło przynosić pewne skutki. Liczne akcje antyterrorystyczne sił palestyńsko-izraelskich znacznie ograniczyły pole manewru Hamasowi. Na bazie tych sukcesów 23 października 1998 roku podpisano porozumienie w Wye Plantation, na mocy którego Izrael zgodził się przekazać następne 13 procent terytorium Zachodniego Brzegu Jordanu podzielonego na trzy strefy A, B i C. Nad pierwszą z nich obejmującą 3 procent tego obszaru Autonomia przyjęła kontrolę po porozumieniach z Oslo i Waszyngtonu. Strefa B obejmującą 24 procent obszaru miała być zarządzana przez administrację palestyńską, jednak w gestii Izraela pozostawało pilnowanie bezpieczeństwa. W strefie C czyli na 73 \% obszaru całkowitą władzę sprawować miał Izrael. Ponadto władze autonomii zobowiązały się do ostatecznego usunięcia z Karty Narodowej zapisu o konieczności likwidacji Izraela ${ }^{24}$.

Porozumienie to spotkało się z ostrą reakcją środowisk radykalnych, które zarzucały władzom Autonomii zaprzedanie się „syjonistycznemu” wrogowi. Wywołało to kolejną falę zamachów samobójczych na terenie Palestyny, z których najsłynniejszy miał miejsce w Jerozolimie 6 listopada 1998 roku. Wśród ofiar było 2 zabitych i 21 rannych. Nie przeszkodziło to jednak ratyfikacji porozumień przez Parlament Izraelski, a wkrótce rząd izraelski przystąpił do wycofania się z części ziem Zachodniego Brzegu. Również dobrą wolą wykazała się strona palestyńska dokonując konfiskaty nielegalnej broni na terytorium autonomii, a Arafat oświadczył, że nie będzie dokonywał żadnych sojuszy, które miałyby być wymierzone w Izrael $^{25}$.

\footnotetext{
22 Ch. Reuter, Zamachowcy - Samobójcy, Warszawa 2003, s. 136.

23 A. Krawczyk, op. cit., s. 232.

24 B. Bolechów, op. cit., s. 312-313.

25 Ł. Marciniak, op. cit., s., 58.
} 
4 września 1999 roku podpisano kolejny układ miedzy stronami w egipskim kurorcie Szarm El Szejk, na który terroryści zareagowali podkładając materiały wybuchowe w Hajfie i Tyberiadzie - zginęło wówczas trzech zamachowców a cztery osoby zostały ranne. Coraz mniejsza liczba ofiar świadczyła o stopniowej zmianie strategii przez Hamas. Zdecydowany wpływ na nią miały przede wszystkim: uwolnienie Szejka Jasmina ${ }^{26}$ i zmiany wewnątrz struktury organizacji. Do głosu zaczęli dochodzić przedstawiciele wewnętrznego przywództwa, kładący większy nacisk na działalność społeczną i propagandową. Zewnętrzne przywództwo rezydujące głównie w Jordanii, odebrało tego typu gesty jako zdradę interesów palestyńskich. Jednak zmiana władzy w tym państwie w 1999 roku oraz naciski USA i Izraela, spowodowały zaostrzenie kursu wobec działaczy palestyńskich. Te działania były na rękę Jassinowi, ze względu na fakt, że osłabiały frakcje terrorystyczne w łonie Hamasu. Wydarzenia te doprowadziły do ograniczenia intensywności zamachów terrorystycznych oraz zmiany ataków samobójczych na mniej destrukcyjne. W połowie października 1999 roku militarne skrzydło Hamasu oświadczyło, ze obecna sytuacja polityczna zmusza ich do czasowego zaprzestania operacji zbrojnych ${ }^{27}$.

Przedłużające się pertraktacje pokojowe, brak perspektyw Palestyńczyków, a przede wszystkim wybuch kolejnej intifady (powstanie Al-Aksa) po raz kolejny odwróciły te proporcje.

Drugą intifadę należy wiązać z załamaniem się bliskowschodniego procesu pokojowego po fiasku szczytu przywódców Izraela, Palestyny i USA w Camp David 11-25 lipca 2000 roku, na którym status Jerozolimy i Wzgórza Świątynnego był jedną z kwestii spornych. Metody walki stosowane przez Palestyńczyków były podobne do pierwszej intifady, aczkolwiek pojawiły się też zamachy samobójcze i ostrzał prymitywnymi rakietami typu Qassam. Po zwycięstwie wyborczym Szarona 6 lutego 2001 roku nowe władze izraelskie postawiły na siłową rozprawę $\mathrm{z}$ intifadą, co doprowadziło do eskalacji przemocy ${ }^{28}$.

18 grudnia 2003 roku izraelski premier Ariel Szaron przedstawił własny plan rozwiązania konfliktu izraelsko-palestyńskiego drogą pokojową. Szaron powie-

26 „W 1997 roku na mocy porozumienia izraelsko-jordańskiego Yassin został zwolniony z więzienia i powrócił do Gazy. Jego zwolnienie nastąpiło pod warunkiem powstrzymania się od nawoływania do zamachów terrorystycznych przeciwko Izraelowi. Yassin ponownie stanął na czele Hamasu i wznowił swoją propagandę nienawiści do Izraela”; http://www.izrael.badacz.org/historia/intifada_ hamas.html (dostęp: 21.02.2013 r.).

27 B. Bolechów, op. cit., 317.

28 J. Wójcik, Intifada AL.-AQsa: Spontaniczny zryw społeczeństwa czy element politycznej strategii palestyńskiego establishmentu? Przyczyny wybuchu powstania palestyńskiego w 2000 roku, [w:] Izrael i Autonomia Palestyńska. Wybrane aspekty polityczne i prawne, red. J. Bernard, A. Tokarz, G. Tokarz, Wrocław 2007, s. 4. 
dział, że jeśli impas w konflikcie będzie trwał, jego kraj wytyczy nowe „linie bezpieczeństwa”, oddzielające Izrael od terytoriów palestyńskich na Zachodnim Brzegu i w Strefie Gazy. Plan zakładał wcześniejsze powstanie państwa palestyńskiego i likwidację części osiedli żydowskich. Nowe granice miały być chronione przez budowaną „barierę bezpieczeństwa”. To posunięcie spotkało się z oskarżeniem, że poprzez wytyczone w ten sposób granicy Izrael bezprawnie anektuje część terytorium Zachodniego Brzegu Jordanu. Plan został zaakceptowany przez strony konfliktu. Wiązano z nim wielkie nadzieje. Pomimo tego, doszło do pierwszych zakłóceń procesu pokojowego. W odpowiedzi 22 lutego 2004 roku - zamachowiec-samobójca wysadził się w autobusie w centrum Jerozolimy zabijając 7 Izraelczyków i raniąc 66 osób. W odwecie izraelska armia zintensyfikowała działania wymierzone przeciwko Hamasowi, zabijając w Gazie duchowego przywódcę Hamasu, szejka Ahmeda Jasina ${ }^{29}$.

Zamachy samobójcze w czasie powstania były głównym elementem strategii Hamasu. Zabójstwa głównych przywódców Hamasu Shehade w 2002 roku, Szejka Jassina w 2004 roku i Abdela Rantissi (następcy Jassina) sprawiły, że liczba ataków terrorystycznych wzrosła pięciokrotnie, przy czym wskaźnik śmiertelności ataków Hamasu spadł z najwyższego punktu w 2002 roku do najniższego punktu, w roku 2005, mimo że liczba ataków wzrosła, co sugeruje, że ataki stały się mniej skuteczne ${ }^{30}$ (dane prezentuje tabela nr 1).

Tabela 1.

\begin{tabular}{|c|c|c|c|}
\hline Rok & Ataki Hamasu* & Śmierć cywilów** & $\begin{array}{c}\text { Wskaźnik } \\
\text { śmiertelności }\end{array}$ \\
\hline 2002 & 34 & 185 & $5.9 \%$ \\
\hline 2003 & 46 & 45 & $0.98 \%$ \\
\hline 2004 & 202 & 67 & $0.33 \%$ \\
\hline 2005 & 179 & 22 & $0.11 \%$ \\
\hline
\end{tabular}

Źródło: opracowanie własne.

* D. Byman, Do Targeted Killings Work? Foreign Affairs, http://www12.georgetown.edu/sfs/ cpass/Articles/BymanTargetedKillings.pdf (dostęp: 21.03.2013 r.).

** National Memorial Institute for the Prevention of Terrorism, MIPT, http://www.mipt.org/ (dostęp: 21.03.2013 r.).

${ }_{29}$ M. Giec, Wybuch pierwszej intifady i początek rozmów izraelsko-palestyńskich, http://www. psz.pl/tekst-2766/Wybuch-pierwszej-intifady-i-poczatek-rozmow-izraelsko-palestynskich/Str(dostęp: 04.04.2013 r.).

$30 \mathrm{~J}$. Goldings, Targedet killings in the AL-Aqsa intifada an examination of changes in Hamas operation capacity, Waszyngton 2011, s. 28. 
Wyniki te sugerują, że Hamas w dużym stopniu polegał na umiejętności i charyzmie swoich liderów. Ich śmierć wpływała na zdolność operacyjną Hamasu, bo choć grupa zintensyfikowała przemoc przeprowadzając więcej ataków, to jednak nie były one już tak skuteczne.

Wraz ze śmiercią Jasira Arafata stopniowo wygasała siła powstania palestyńskiego Za oficjalny koniec drugiej intifady można uznać rozejm ogłoszony przez przywódców Izraela i Palestyny Ariela Szarona i Mahmuda Abbasa 8 lutego 2005 roku na szczycie w Szarm el-Szejk, aczkolwiek nie przyniósł on całkowitego ustania przemocy. Konsekwencją drugiej intifady było dalsze umacnianie się radykalnego Hamasu w związku z demokratyzacją władz palestyńskich pod naciskiem USA, co znalazło wyraz w zwycięstwie Hamasu w wyborach parlamentarnych w Autonomii Palestyńskiej 25 stycznia 2006 roku $^{31}$.

Polityczna transformacja Hamasu nie była wydarzeniem nagłym, ale stałą ewolucją sposobu myślenia, która wzmogła się po ogłoszeniu hudny koncepcji pokojowego współistnienia z Izraelem opartym na wzajemnym zakończeniu przemocy, która zawierała propozycję ostatecznego rozwiązania sporu. Jeden z przywódców Hamasu zauważył w tym czasie, że w rezultacie pojawienia się tej pokojowej inicjatywy poparcie dla Hamasu wśród ludności wzrosło. Zauważył też z satysfakcją, że polityczne działania mogą być bardziej popularne niż sam opór ${ }^{32}$.

Hamas, wygrywając wybory do parlamentu i obejmując zbrojnie władzę w Strefie Gazy, znalazł się w jakościowo nowej dla siebie sytuacji. Działając wcześniej jako organizacja paramilitarna o jasno sprecyzowanych celach i chętnie sięgająca do metod terrorystycznych, nie musiał troszczyć się o sferę polityczną i społeczno-ekonomiczną swej aktywności. Obejmując władzę, zmuszony został jednak do przejęcia pełni odpowiedzialności za wszystkie aspekty funkcjonowania infrastruktury i administracji Strefy oraz jej mieszkańców. Rządy Hamasu dowiodły, aż nadto dobrze, że odpowiedzialność ta wyraźnie go przerosła - położenie ekonomiczne i warunki życia Palestyńczyków w Gazie uległy w tym okresie dalszemu dramatycznemu pogorszeniu, a cała Strefa znalazła się wręcz na krawędzi katastrofy humanitarnej. Poparcie społeczne dla Hamasu - dotychczas utrzymujące się na poziomie ok. $60 \%$, zaczęło gwałtownie spadać ${ }^{33}$.

Spośród 132 mandatów parlamentarnych Hamas otrzymał 76. Fatah z liczbą 46 deputowanych poniósł porażkę. Okazało się, że Islamski Ruch Oporu miał do-

31 E. Barbur, K. Urbański, Wtaśnie Izrael. „Gadany” przewodnik po teraźniejszości i historii Izraela, Warszawa 2006, s. 100.

32 A. Crooke, Od ruchu powstańczego do partii politycznej. Przypadek transformacji Hamasu, http://www.arabia.pl/content/view/289463/111/ 16/06/2007 (dostęp: 10.03.2013 r.).

33 T. Otłowski, Izraelska operacja wojskowa w strefie Gazy, Policy Papers 2009, nr 1, s. 2. 
minującą pozycję nie tylko w Strefie Gazy, lecz także na Zachodnim Brzegu Jordanu. W marcu 2006 roku ukonstytuował się nowy gabinet. Na jego czele stanął Ismail Haniyeh. Życie polityczne Autonomii dalekie było jednak od wewnętrznej stabilizacji. Dość szybko ujawniły się różnice zdań w fundamentalnych kwestiach, co zaogniło stosunki na linii Haniyeh - Abbas. Napięta sytuacja skłoniła prezydenta Mahmuda Abbasa do podjęcia nadzwyczajnych środków ostrożności polegających na wprowadzeniu stanu wyjątkowego, rozwiązaniu parlamentu oraz zdymisjonowaniu rządu Haniyeha. Na czele nowego gabinetu stanął Salam Fayyad. W Autonomii rozpoczął się okres dwuwładzy: Hamas był dominującym podmiotem w Strefie Gazy, Fatah na Zachodnim Brzegu Jordanu ${ }^{34}$.

Okres kohabitacji trwał bardzo krótko. Już niebawem doszło do zamachu stanu w Strefie Gazy, gdzie hamasowcy powołali separatystyczny w stosunku do Zachodniego Brzegu Jordanu gabinet. Palestyńczycy nie jednoczyli się już w walce przeciwko Państwu Żydowskiemu, lecz kierowali broń przeciwko sobie. Awantury wewnętrzne wśród Palestyńczyków osłabiały szanse na pokój i pogłębiały niestabilność w regionie. Po przejęciu władzy przez Hamas władze Izraela rozpoczęły bezprecedensową blokadę Strefy Gazy, wstrzymując eksport i import towarów oraz ograniczając dostawy wody, prądu i elektryczności doprowadzając do katastrofy humanitarnej35. Palestyńczycy w odpowiedzi zbudowali sieć tuneli podziemnych (350) łączących terytorium Strefy Gazy z Egiptem ${ }^{36}$. Skrawek ziemi o powierzchni $350 \mathrm{~km}^{2}$ stał się największym więzieniem dla $1,5 \mathrm{mln}$ ludzi. Ekstremalne represalia zastosowane przez Żydów podsycały chęć ekstremalnego odwetu Palestyńczyków ${ }^{37}$.

27 grudnia 2008 roku rozpoczęła się agresja Izraela na Strefę Gazy okryta kryptonimem „Płynny ołów”, której celem była likwidacja członków i zniszczenie infrastruktury Hamasu w Strefie Gazy. Bezpośrednią przyczyną rozpoczęcia działań zbrojnych było wznowienie ostrzału terytorium Izraela przez Islamski Ruch Oporu oskarżający Izrael o niezniesienie blokady Strefy Gazy i powtarzające się rajdy wojsk izraelskich na terytorium $\mathrm{Gazy}^{38}$.

W ciągu 22-dniowych działań zbrojnych zginęło 1188 ludzi ( w tym 410 dzieci, 100 kobiet), a 5285 było rannych. Brutalna interwencja obróciła ten wąski

34 S. Niedziela, Kwestia palestyńska a eskalacja konfliktu 2008-2009, Zeszyty Naukowe Akademii Marynarki Wojennej 2009, nr 3, s. 72.

35 Wptyw blokady ekonomicznej na sytuacje humanitarna Gazy, http://mondediplomatique.pl/ LMD53/index.php?id=2_2 (dostęp: 17.02.2013 r.).

36 P. Saint-Paul, Dans les tunnels de Gaza aux mains du Hamas, Le Figaro 13.06.2008.

37 S. Niedziela, op. cit., s. 81.

38 P. Smoleński, Gaza w ogniu, http://wyborcza.pl/1,76842,6115986,Gaza_w_ogniu.html (dostęp: 08.04.2013 r.). 
skrawek ziemi w perzynę. Jak pisał hiszpański dziennik „La Vanguardia”: „Spacer alejami Gazy nie różni się od wizyty w Muzeum Holokaustu”39.

Największy kryzys na Bliskim Wschodzie wymagał natychmiastowego wszczęcia wysiłków dyplomatycznych służących rozwiązaniu krwawego konfliktu. Wiele podmiotów międzynarodowych wzywało do niezwłocznego przerwania ognia: ONZ, Unia Europejska, NATO, Stany Zjednoczone, Rosja, Chiny, Liga Państw Arabskich. W sprawie Gazy przewodnią rolę odegrała dyplomacja francuska. Słusznie uznano, że jakiekolwiek porozumienie między Hamasem a Izraelem będzie możliwe dzięki współpracy USA, Egiptu i Syrii. Warunki przerwania ognia były następujące: wycofanie wojsk izraelskich z Gazy; zaprzestanie ostrzału terytorium Izraela z Gazy przez bojowników Hamasu. Do natychmiastowego przerwania ognia i otwarcia korytarzy humanitarnych wzywała przyjęta w nocy z 8 na 9 stycznia 2009 roku rezolucja 1860 Rady Bezpieczeństwa ONZ. Ostatecznie po 22 dniach bombardowań lądowo-powietrznych na Strefę Gazy udało się osiągnąć porozumienie. Tel Awiw prowadził separatystyczne rozmowy z przywódcami USA i 17 stycznia rząd Izraela ogłosił jednostronne przerwanie ognia. Podział w Autonomii Palestyńskiej był korzystny dla prawicowych rządów w Jerozolimie, które - stosując sprawdzoną taktykę dziel i rządź - mogły bezkarnie kolonizować Zachodni Brzeg i organizować zbrojne wypady do Strefy Gazy ${ }^{40}$. Taki stan rzeczy nie mógł trwać jednak wiecznie. Szansa na przełamanie impasu w relacjach między największymi frakcjami palestyńskimi przyszła w 2009 roku. To właśnie wówczas, przy udziale egipskich mediacji, w Kairze przedstawiciele 13 palestyńskich grup, w tym przede wszystkim Hamasu i Fatahu, ogłosili zakończenie dwudziestomiesięcznego okresu bez oficjalnych kontaktów. Ten, jak wówczas mówiono, historyczny dzień nie doprowadził jednak do znaczącego postępu w zakopaniu przepaści dzielącej rządy z Gazy i Ramallah. Ostatecznie udało się osiągnąć kompromis z dniem 27 kwietnia 2011 roku kończący lata rywalizacji między Hamasem i Fatahem i zakładającego utworzenie:

- państwa palestyńskiego w granicach z 1967 r., z Jerozolimą Wschodnią jako stolicą i utrzymaniem prawa uchodźców do powrotu

- $\quad$ kolejnego rządu jedności narodowej mającego doprowadzić do wyborów $\mathrm{w} \mathrm{AP}^{41}$.

39 La razón de la sinrazón, La Vanguardia 11.01.2009.

40 M. Lipa, Palestyńska gorączka, http://www.przeglad-tygodnik.pl/pl/artykul/palestynska-goraczka (dostęp: 12.06.2013 r.).

41 D. Wach, Palestyńczycy chca pojednania, nie rewolucji, http://www.psz.pl/tekst-37689/Palestynczycy-chca-pojednania-nie-rewolucji (dostęp: 21.02.2013 r.). 
Jednym z czynników wznowienia rokowań i starań na drodze do zjednoczenia palestyńskiego ruchu narodowego była arabska wiosna, a także sukcesy jakie odniosły partie islamskie na Bliskim Wschodzie ${ }^{42}$. Choć bezpośrednio nie zaobserwowano wystąpień samych Palestyńczyków, podobnych do tych z Kairu, Tunisu czy Damaszku, to zajęli oni stanowisko względem swoich przywódców. Mieszkańcy Gazy i Zachodniego Brzegu nie żądali obalenia dotychczasowej władzy, lecz domagali się zakończenia wewnątrzpalestyńskiego podziału i wspólnej walki z okupacją. Biorąc pod uwagę dużą wrażliwość Hamasu na nastroje społeczne oraz fakt, iż to głównie mieszkańcy Strefy Gazy, będącej pod kontrolą tego ugrupowania, domagali się pojednania jest to czynnik nie do przecenienia ${ }^{43}$.

\section{Wnioski}

Zmiany, jakie nastąpiły i nadal następują w świecie arabskim okazały się dla Hamasu ciężkim wyzwaniem lojalności. Otóż państwa, które przez lata wspierały ruch zaczęły mieć ogromne problemy. $\mathrm{Na}$ fali rewolucji sytuacja w samym łonie przywódców palestyńskich całkowicie się zmieniła - nastąpiło nie tylko zbliżenie z Fatahem, ale również wyrzeczenie używania przemocy. Przez takie racjonalne i trzeźwe spojrzenie na sytuację w regionie przywódcy Islamskiego Ruchu Oporu wyczuli swoją szansę na odnalezienie się na palestyńskiej scenie politycznej i tym samym doprowadzenie do unormowania wewnętrznej sytuacji, ale także na zaistnienie na szerszym polu ${ }^{44}$.

Hamas zawsze był zaangażowany politycznie i militarnie w sprawę palestyńską torpedując atakami terrorystycznymi porozumienia pokojowe między Izraelem a Autonomią próbując udowodnić, że przy pomocy tzw. pokojowych rozwiązań i konferencji nie sposób zaprowadzić pokoju między zwaśnionymi stronami. $\mathrm{Z}$ drugiej strony to właśnie zamachy terrorystyczne były głównym powodem, dla których negocjacje te były podejmowane ${ }^{45}$.

42 F. Ghitis, W zmieniającym się regionie, Hamas musi pilnie dokonywać wyborów, http://www. stosunkimiedzynarodowe.info/artykul,1221,W_zmieniajacym_sie_regionie_Hamas_musi_pilnie_dokonac_wyborow (dostęp: 10.04.2013 r.).

43 D. Wach, Palestyńczycy chca pojednania, nie rewolucji, http://www.psz.pl/tekst-37689/Palestynczycy-chca-pojednania-nie-rewolucji (dostęp: 10.03.2013 r.).

44 M. Sobczak, Arabka wiosna oczami Hamasu, http://www.politykaglobalna.pl/2012/05/arabska-wiosna-oczami-hamasu/ (dostęp: 30.05.2012 r.).

45 A. Gray, Hamas non-violent political activites, http://www.globalsecuritystudies.com/Amber \%20HAMAS.pdf -, (dostęp: 23.05.2012 r.). 
Dwaj izraelscy politolodzy Szau Mishal i Abraham Sela dokonali swoistej analizy podsumowującej dotychczasowy doktrynalny dorobek organizacji. Ocenili oni, że: „Hamas nie jest więźniem swojego własnego dogmatu. Nie chowa się za absolutnymi prawdami, ani nie podporządkowuje swoich działań i decyzji oficjalnej doktrynie religijnej. Działa raczej jako wypadkowa okazji i ograniczeń podejmuje zmieniające się życzenia i potrzeby ludności palestyńskiej, bardzo dokładnie rozpoznając przy tym możliwości polityczne i układ sił ${ }^{46}$.

46 Ch. Reuter, op. cit., s. 133. 